\section{Integration of No Tillage and Overseeded Legume Living Mulches for Transplanted Broccoli Production}

\author{
Michelle L. Infante ${ }^{1}$ and Ronald D. Morse ${ }^{2}$ \\ Department of Horticulture, Virginia Polytechnic Institute and State University, \\ Blacksburg, VA 24061-0327
}

Additional index words. Brassica oleracea var. italica, sustainable agriculture, conservation tillage, weed suppression

\begin{abstract}
Experiments were conducted with 'BigSur' broccoli (Brassica oleracea L. var. italica) at two sites in Fall 1993 and at two sites in Spring 1994 on a Hayter loam in southwestern Virginia. Our objectives were to determine the effects of tillage main plots (conventional tillage $=\mathrm{CT}$ and no tillage $=\mathrm{NT}$ ) and weed control subplots [no overseeding or preemergent herbicide, oxyfluorofen, red clover (Trifolium pratense L.), 'Dutch' white clover (Trifolium repens L.), and hairy vetch (Vicia villosa Roth)] on broccoli yield and weed suppression. In all sites, weed suppression and marketable broccoli yield with NT were equal to or higher than with CT. Overseeded legume living mulches did not affect broccoli yield in any site compared to the control plots and suppressed weeds as well as the oxyfluorofen in three of the four sites. Thus, the NT systems used in these experiments can suppress weeds and produce high broccoli yields. Also, overseeded legume living mulches can be established effectively after transplanting to suppress weeds without reducing broccoli yield. Chemical name used: 2-choro-1-(3-ethoxy-4-nitrophenoxy)-4(trifluoromethyl) benzene (oxyfluorofen).
\end{abstract}

Sustainable agriculture has gained popularity in recent years due to concerns for the environment and efficient crop production systems. Sustainable production methods include no tillage (NT) and integrated weed management systems that conserve and often improve soil quality (Karlen and Stott, 1994). Although conservation tillage methods have been used successfully in agronomic crops for many years, vegetable producers have been reluctant to adopt conservation tillage because research and on-farm trials have not given consistent positive results (Hoyt et al., 1994; Wilhoit et al., 1990). In recent years, however, improvements in establishment of transplanted vegetables in NT systems have resulted in greater yield stability, often achieving yields equal to or higher than those with conventional tillage (CT) (Hoyt et al., 1994; Morse, 1995a; Morse et al., 1993).

Conservation tillage systems, and particularly NT systems, greatly improve soil moisture conditions and plant survival during dry periods. In many studies, NT soil moisture is higher than in CT soil throughout the growing season (Knavel and Herron, 1981; Morse, 1993). Increased soil moisture frequently improves crop yields but also can enhance weed growth (Hoyt et al., 1994).

Lack of effective herbicides often leads to weed control problems in NT vegetable pro-

\footnotetext{
Received for publication 2 Oct. 1995. Accepted for publication 21 Dec. 1995. The cost of publishing this paper was defrayed in part by the payment of page charges. Under postal regulations, this paper therefore must be hereby marked advertisement solely to indicate this fact.

${ }^{1}$ Graduate Research Assistant.

${ }^{2}$ Associate Professor.
}

duction (Hoyt et al., 1994; Standifer and Beste, 1985). In NT plantings, cultivation requires undesirable heavy equipment and negates the advantages of NT residue management systems. However, overseeding after plant establishment to obtain a uniform stand of living mulch (LM) and suppress emerging weeds is an ideal sustainable practice (Regnier and Janke, 1991) and is particularly effective in a NT field in which the soil surface is left undisturbed before and after transplanting (Morse, 1995a, 1995b). Transplanted crops likely are particularly adaptive to overseeding because transplants have an initial size advantage over post-transplant emergence and growth of weeds and overseeded species. In addition to controlling weeds, LMs can minimize erosion, decrease soil temperature, improve water infiltration rate, improve soil structure, favor microbial activity, and increase crop yield (Akobundu, 1980). Thus, the benefits of LMs and NT production systems are similar (Coolman and Hoyt, 1993b).

In most NT systems, all live vegetation is desiccated with contact herbicides before planting to achieve a weed-free, stale-seedbed environment (Hoyt et al., 1994; Standifer and Beste, 1985). The stale-seedbed technique is a form of limited tillage normally applied to plow-disk systems in which a flush of new weed seedlings germinating after tillage is killed with chemicals before planting the cash crop (Standifer and Beste, 1985). Often, the desiccated residues rapidly decompose after planting, exposing the soil to potential erosion and soil-moisture deficits. Overseeding can maintain the integrity of the NT system by replacing the dead, decaying mulch with a noncompetitive LM. After harvesting the main crop and chopping the remaining crop resi- dues to facilitate decomposition, the overseeded LMs can become valuable overwintering cover crops. This vegetable or LM intercropping system is a convenient and efficient sustainable method for reducing soil erosion on steep, highly erodible land and maintaining a favorable habitat for beneficial insects (Bugg et al., 1990; Coolman and Hoyt, 1993b; Wiles et al., 1989). When using LM, the challenge is to maintain the many advantages of a NT system without reducing crop yield by competing with the main crop for water, nutrients, space, and sunlight (Costello, 1994; Graham and Crabtree, 1987; Lal et al., 1991; Regnier and Janke, 1990). Research on integration of post-transplant establishment of LM into NT systems for vegetable crops is limited (Coolman and Hoyt, 1993b). Based on preliminary data (Foulds et al., 1991; Serage, 1993), overseeding legume cover crops after transplanting broccoli can suppress weeds without reducing yield. However, research is needed to properly identify and quantify the major crop ecological determinants of the interspecific competition involved and the associated best management practices for success.

Our objective was to determine the feasibility of using overseeding legume LMs for weed control in a fertile, irrigated, NT broccoli production system. Broccoli yield and weed biomass were determined as indicators of tillage and LM effects.

\section{Materials and Methods}

Field experiments were conducted at two sites in Fall 1993 (FC) and at two sites in Spring 1994 (SC) at the Virginia Polytechnic Institute and State Univ. Kentland Agricultural Research Farm, Blacksburg. The soil at all sites was a Hayter loam (fine-loamy, mixed, mesic, Ultic Hapludalf) with a $\mathrm{pH}$ varying from 6.5 to 7.0. Soil tests showed that P, K, Ca, and $\mathrm{Mg}$ levels at all sites were very high, high, very high, and high, respectively. At each site, the design was a split plot with main plots arranged in four randomized complete blocks. Main plots $(\mathrm{FC}=7.3 \times 15.4 \mathrm{~m}$ and $\mathrm{SC}=30.5$ $\times 3.7 \mathrm{~m})$ were tillage systems: NT and CT. Subplots $(\mathrm{FC}=7.3 \times 3.1 \mathrm{~m}$ and $\mathrm{SC}=6.1 \times 3.7$ m) were weed control treatments: control (no legume mulch and no preemergent herbicide), oxyfluorofen herbicide (HB) (one application of preemergent herbicide), red clover, 'Dutch' white clover, and hairy vetch.

Tillage systems. On 7 June 1993, foxtail millet (Setaria italica L.) was drilled in one site (FC/M) at $34 \mathrm{~kg} \cdot \mathrm{ha}^{-1}$, and soybean (Glycine $\max \mathrm{L}$.) was drilled in a second site (FC/S) at $98 \mathrm{~kg} \cdot \mathrm{ha}^{-1}$. On 11 Nov. 1993, cereal rye (Secale cereale $\mathrm{L}$.) was drilled in two sites (SC/R1 and SC/R2) at $188 \mathrm{~kg} \cdot \mathrm{ha}^{-1}$. For FC and SC plantings, the two sites were located within $75 \mathrm{~m}$ of each other and had similar soil physical and chemical properties. The cover crops were desiccated with $N$-(phosphonomethyl) glycine (glyphosate) at $3.4 \mathrm{~kg}$ a.i./ha 1 week before planting broccoli. Before transplanting, the desiccated cover crop residues were either flail-mowed in FC sites or left intact in $\mathrm{SC}$ sites. Cover crop residues were left on the 
Table 1. Summary of analysis of variance indicating significant source effects on between-row and in-row living biomass and weed biomass at two sites in Fall 1993.

\begin{tabular}{|c|c|c|c|c|c|c|c|c|c|c|}
\hline \multirow[b]{3}{*}{ Source } & \multirow[b]{3}{*}{ df } & \multicolumn{4}{|c|}{ Living mulch biomass } & \multirow[b]{3}{*}{ df } & \multicolumn{4}{|c|}{ Weed biomass } \\
\hline & & \multicolumn{2}{|c|}{ Between row } & \multicolumn{2}{|c|}{ In row } & & \multicolumn{2}{|c|}{ Between row } & \multicolumn{2}{|c|}{ In row } \\
\hline & & $\mathrm{SS}^{\mathrm{z}}$ & $P>\mathrm{F}$ & SS & $P>\mathrm{F}$ & & $\mathrm{SS}^{\mathrm{z}}$ & $P>\mathrm{F}$ & SS & $P>\mathrm{F}$ \\
\hline Total & 47 & & & & & 79 & & & & \\
\hline Site $(\mathrm{S})$ & 1 & 772,161 & 0.0001 & 27,648 & 0.0001 & 1 & $239,158,738$ & 0.0001 & $19,945,037$ & 0.0001 \\
\hline Error a & 6 & 22,099 & & 2,115 & & 6 & 116,106 & & 58,075 & \\
\hline Tillage $(\mathrm{T})$ & 1 & 106,032 & 0.0021 & 4,033 & 0.0251 & 1 & $40,579,732$ & 0.0001 & $13,618,275$ & 0.0001 \\
\hline $\mathrm{S} \times \mathrm{T}$ & 1 & $3,076,481$ & 0.0001 & 24,300 & 0.0003 & 1 & $2,799,390$ & 0.0006 & $8,126,213$ & 0.0001 \\
\hline Error b & 6 & 28,822 & & 2,750 & & 6 & 392,032 & & 27,274 & \\
\hline Weed control method (WCM) & 2 & 8,034 & 0.2095 & 261,689 & 0.0001 & 4 & $113,067,148$ & 0.0001 & $7,312,405$ & 0.0001 \\
\hline $\mathrm{S} \times \mathrm{WCM}$ & 2 & $4,442,045$ & 0.0001 & 227,598 & 0.0001 & 4 & $56,600,148$ & 0.0001 & $7,041,562$ & 0.0001 \\
\hline $\mathrm{T} \times \mathrm{WCM}$ & 2 & $2,108,162$ & 0.0001 & 8,205 & 0.0016 & 4 & $8,238,821$ & 0.0001 & $8,937,312$ & 0.0001 \\
\hline $\mathrm{S} \times \mathrm{T} \times \mathrm{WCM}$ & 2 & 139,813 & 0.0001 & 57,554 & 0.0001 & 4 & $5,220,367$ & 0.0001 & $9,117,556$ & 0.0001 \\
\hline Error c & 24 & 57,755 & & 11,627 & & 48 & $2,676,135$ & & 174,745 & \\
\hline
\end{tabular}

${ }^{\mathrm{z}} \mathrm{SS}=$ sum of squares.

surface in NT plots and were incorporated using a rotary tiller (model 62-03; Bushhog, Selma, Ala.), leaving a clean surface in CT plots. For NT and CT, HB subplots were sprayed with oxyfluorofen at $0.56 \mathrm{~kg}$ a.i./ha before transplanting broccoli. Crop residue biomass was determined before transplanting by cutting a $0.36-\mathrm{m}^{2}$ sample plot at ground level in each replication at each site and weighing them after drying at $70 \mathrm{C}$ for 2 weeks. Biomass dry weight averaged 6.2, 2.8,2.1, and $1.9 \mathrm{Mg} \cdot \mathrm{ha}^{-1}$ for the FC/M, FC/S, SC/R1, and $\mathrm{SC} / \mathrm{R} 2$ sites, respectively.

Broccoli planting. Bareroot, 6-week-old, 'BigSur' broccoli transplants were produced in seed beds adjacent to the research plots for the FC sites and by Sumner Farms, Tifton, Ga., for the SC sites. The transplants were set (FC/S = 5 Aug. 1993, FC/M = 10 Aug. 1993, and SC/R1 and SC/R2 = 28 Apr. 1994) with a subsurface tiller-transplanter (SST-T) (B\&B No-Till, Laurel Fork, Va.) (Morse et al., 1993). Granular fertilizer was surface-banded at planting $8 \mathrm{~cm}$ from both sides of each row in FC with (in kg.ha ${ }^{-1}$ ) $112 \mathrm{~N}-96 \mathrm{P}-278 \mathrm{~K}-2.2 \mathrm{~B}$ and in SC sites with $84 \mathrm{~N}-72 \mathrm{P}-208 \mathrm{~K}-1.7 \mathrm{~B}$ using the SST-T (Morse et al., 1993). At head initiation, $\mathrm{NaNO}_{3}$ was sidedressed by hand at $56 \mathrm{~kg}$ $\mathrm{N} / \mathrm{ha}$. To ensure a complete stand, transplants that did not survive were replaced by hand. Overhead sprinkler irrigations were used as needed ( $\leq 3 \mathrm{~cm} /$ week) to supplement rainfall at all sites throughout the growing season to minimize moisture stress. Pesticides were applied at planting and at regular intervals thereafter, according to the Virginia Commercial Vegetable Production Recommendations (Virginia Cooperative Extension, 1993). Three double rows $(40,000$ plants/ha) of broccoli were planted in each subplot. Rows were spaced $46 \mathrm{~cm}$ apart and $76 \mathrm{~cm}$ between twin rows (122 $\mathrm{cm}$ center to center); in-row spacing was 41 $\mathrm{cm}$ between plants.

Legume overseeding. Two days after broccoli transplanting, (in kg.ha- $\left.{ }^{-1}\right) 17$ red clover, 11 white clover, and 50 hairy vetch were surface-broadcast by hand on the designated overseeding plots. The legume seeds were inoculated with the proper Rhizobium species just before planting and were mixed thoroughly with $1200 \mathrm{~g}$ of finely ground and sieved soybean meal to ensure even distribution when hand-sowing. Seeds were not incor-

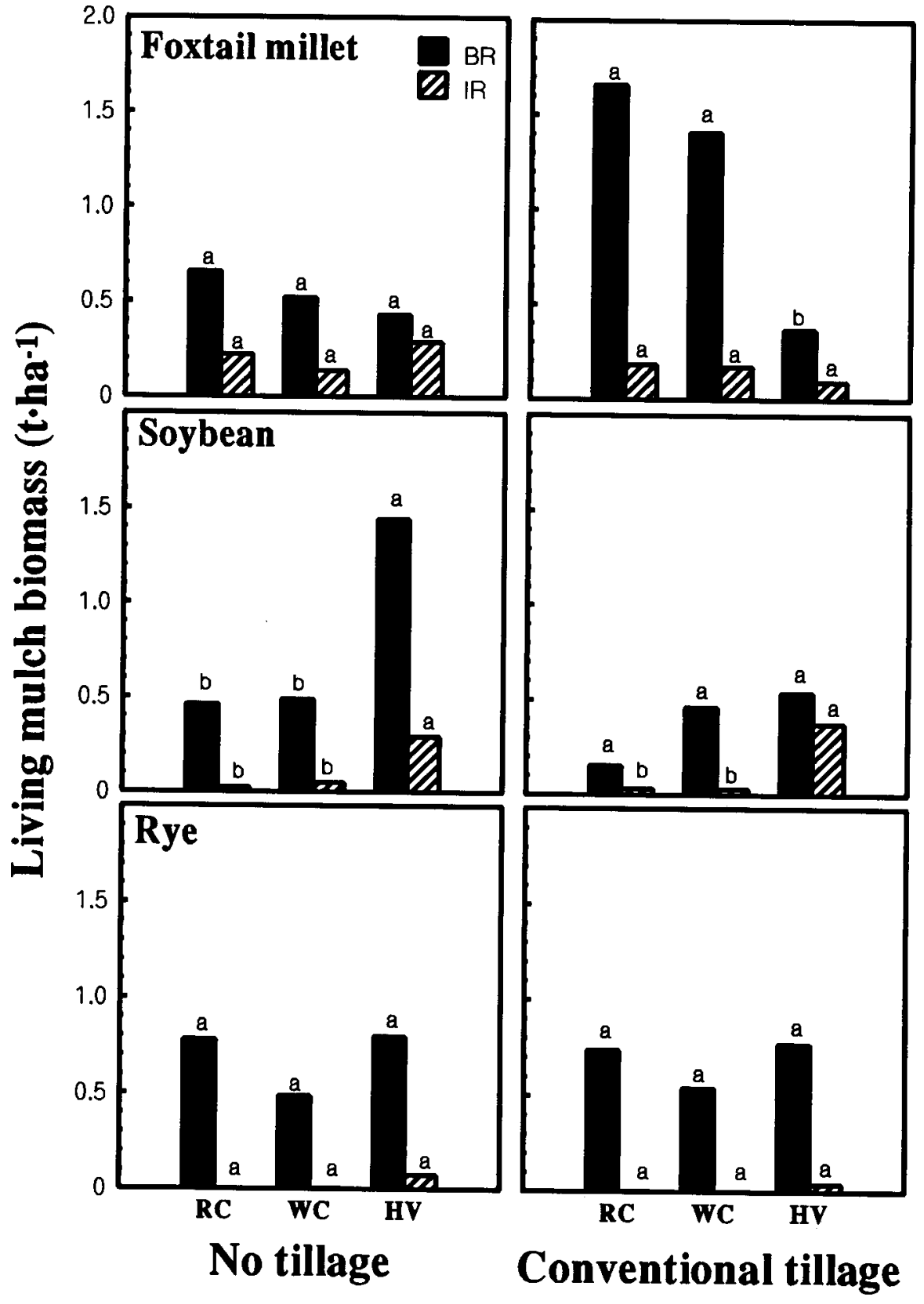

Fig. 1. Dry biomass of red clover, white clover, and hairy vetch harvested 8 weeks after broadcast overseeding into no-tillage and conventional-tillage plots of twin-row broccoli planted into three cover crop sites (foxtail millet, soybean, and rye). Biomass samples were taken from between twin row (BR) and inside twin row (IR) areas of each plot. For each sampling area (BR and IR) and tillage system, mean separation was done using Tukey's honestly significant difference at $P \leq 0.05$. 
porated; however, high surface soil moisture was maintained during the first 2 weeks after transplanting to maximize legume seed germination and transplant survival.

Broccoli leaf analysis. At head initiation stage ( 4 and 5 weeks after transplanting for FC and SC, respectively), young mature broccoli leaves were removed in each subplot, dried at $70 \mathrm{C}$ for 2 weeks, ground with a cyclone mill, and analyzed for $\mathrm{N}$ content using the Kjeldahl procedure (Peterson and Chesters, 1964).

Legume and weed biomass. LM and weed samples $\left(0.36 \mathrm{~m}^{2}\right)$ were taken in all plots between the twin rows (row middles) and inside the twin rows 7 weeks after broccoli transplanting in FC sites and 8 weeks thereafter in SC sites. Samples were separated for legume and weed portions and were weighed after drying for 2 weeks at $70 \mathrm{C}$. The four most prevalent weed species were identified and recorded when samples were taken in the field.

Broccoli harvest. A total of four harvests were taken at weekly intervals for the FC sites, beginning 22 Sept. 1993 in FC/S plots and 26 Sept. 1993 in FC/M plot. Three weekly harvests were taken for the SC sites, beginning 8 June 1994 in SC/R1 and 13 June 1994 in SC/ $\mathrm{R} 2$ plots. Sixteen heads were harvested from the FC sites and 20 from the SC sites. Immediately after harvest, heads were cut to lengths of $19 \mathrm{~cm}$, and fresh weights were recorded.

Statistical analysis. The Statistical Analysis System was used to perform all statistical analysis procedures (Schlotzhauer and Littell, 1987). Two-way analysis of variance was used to determine significance (Norman and Streiner, 1994). For each cropping season (FC and SC), data were combined from the two sites and were analyzed according to Gomez and Gomez (1984). Tukey's honestly significant difference was used for mean separation (Lentner and Bishop, 1993).

\section{Results and Discussion}

For all data shown, site $\times$ tillage interactions were significant $(P \leq 0.05)$ for $\mathrm{FC}$ but not SC (Table 1); therefore, data for FC/M and FC/S are presented separately, while SC/R1 and SC/R2 are combined.

Legume and weed biomass. In FC/S, hairy vetch legume LM biomass was higher than that of red or white clover in all plots, except for between-row CT (Fig. 1). In contrast, in $\mathrm{FC} / \mathrm{M}$, legume LM biomass was the same for all species, except for between-row CT plots, where hairy vetch LM was less than that of red or white clover (Fig. 1). The explanation for this site $\times$ tillage $\times$ weed control method interaction (Table 1) is unknown.

Except in FC/S, the LMs suppressed weeds as well as the HB treatment compared to the control (Fig. 2). There was no difference in weed suppression among the legume LM species in all sites. In-row legume and weed biomass was lower (by $60 \%$ to $99 \%$ ) than corresponding between-row biomass in all sites. Reduced in-row biomass is probably the result of quick canopy closure with the broccoli twin rows (Stoller and Myers, 1988; Tollenaar et al., 1994).
Effects of tillage on broccoli yield. Broccoli yields in NT systems were equal to or higher than yields in CT at all sites (Table 2). Higher yields with NT has been attributed to greater weed suppression and less moisture stress in NT systems (Asoegwu, 1987; Doss et al., 1991). In our experiments, the greatest difference in broccoli yields occurred under heavy weed pressure in FC/S (Fig. 2), where CT yields were $25 \%$ lower than NT (Table 2).

Although not significant in all sites, weed suppression tended to be greater (weed bio- mass was lower) with NT than CT (Fig. 2). This difference in weed suppression can be attributed to at least two factors. First, because planting with the SST-T minimized disturbance of surface residues and surface soil (Morse et al., 1993), the stale-seedbed soil surface was maintained after planting, which probably resulted in the reduced weed seed germination. The soil surface layer under a desiccated cover crop also is a stale seedbed and, if left undisturbed after planting, normally would have fewer viable weed seeds
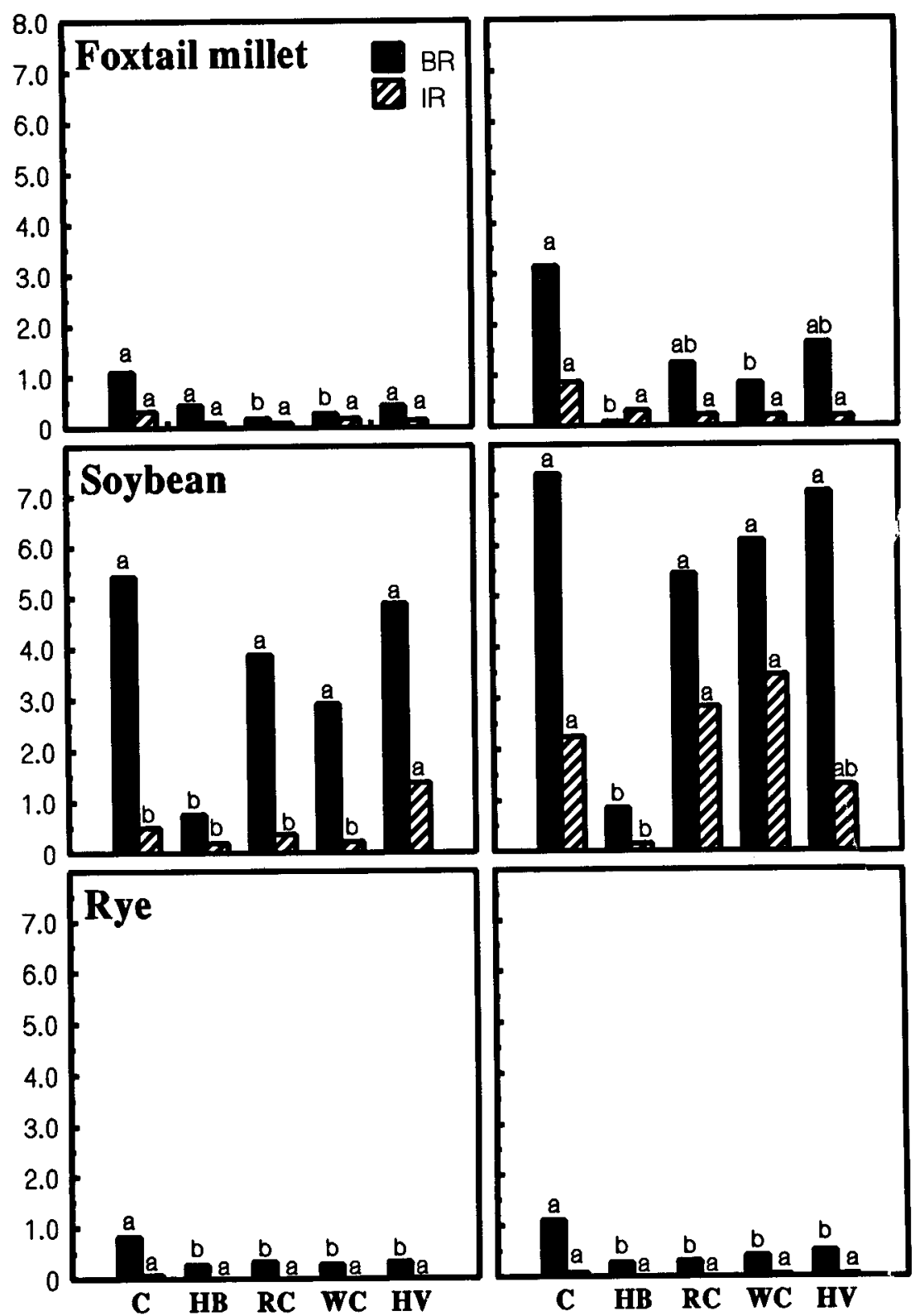

No tillage

Conventional tillage

Fig. 2. Dry weed biomass harvested 8 weeks after transplanting twin-row broccoli into no-tillage and conventional-tillage plots of three cover crop sites (foxtail millet, soybean, and rye). At each cover crop site, five methods of weed control were used [no overseeding or preemergent herbicide (control), oxyfluorofen, red clover, white clover, and hairy vetch]. Weed biomass samples were taken from between twin-row (BR) and inside twin-row (IR) areas of each plot. For each sampling area (BR and IR) and tillage system, mean separation was performed using Tukey's honestly significant difference at $P$ $\leq 0.05$. Weed species, in order of decreasing visual frequency, were Amaranthus retroflexus L., Mollugo verticillata L., Lamium amplexicaule L., and Galinsuga ciliata Raf. in foxtail millet and soybean sites, and Galinsoga ciliata Raf., Amaranthus retroflexus L., Lamium amplexicaule L., and Chenopodium album L. in rye sites. 
Table 2. Effects of tillage and weed control method (WCM) on marketable broccoli yield at three cover crop sites.

\begin{tabular}{|c|c|c|c|c|c|c|c|c|c|}
\hline \multirow{3}{*}{$\begin{array}{l}\text { Weed control } \\
\text { method (WCM) }\end{array}$} & \multicolumn{9}{|c|}{ Yield $\left(\mathrm{Mg} \cdot \mathrm{ha}^{-1}\right)$} \\
\hline & \multicolumn{3}{|c|}{ Foxtail millet, 1993} & \multicolumn{3}{|c|}{ Soybean, 1993} & \multicolumn{3}{|c|}{ Rye, 1994} \\
\hline & $\mathrm{NT}^{2}$ & $\mathrm{CT}^{2}$ & WCM mean & $\mathrm{NT}^{2}$ & $\mathrm{CT}^{2}$ & WCM mean & $\mathrm{NT}^{2}$ & $\mathrm{CT}^{\mathrm{z}}$ & WCM mean \\
\hline None & 16.9 & 15.4 & 16.2 & 13.8 & 11.4 & $12.6 \mathrm{~b}^{\mathrm{y}}$ & 9.5 & 8.5 & 9.0 \\
\hline Herbicide & 16.7 & 17.0 & 16.8 & 17.1 & 15.5 & $16.3 \mathrm{a}$ & 9.2 & 8.2 & 8.7 \\
\hline Red clover & 16.2 & 16.0 & 16.1 & 14.9 & 10.3 & $12.6 \mathrm{~b}$ & 9.5 & 8.5 & 9.0 \\
\hline White clover & 18.2 & 14.2 & 16.2 & 17.4 & 10.1 & $13.7 \mathrm{~b}$ & 9.0 & 8.3 & 8.7 \\
\hline Hairy vetch & 17.1 & 12.5 & 14.8 & 14.8 & 11.4 & $13.1 \mathrm{~b}$ & 9.4 & 8.6 & 9.0 \\
\hline Tillage mean & 17.0 & 15.0 & & 15.6 & 11.7 & & 9.3 & 8.4 & \\
\hline \multicolumn{10}{|l|}{ Treatment effects } \\
\hline Tillage $(\mathrm{T})$ & \multicolumn{3}{|c|}{ NS } & \multicolumn{3}{|c|}{ * } & \multicolumn{2}{|c|}{ * } & \\
\hline WCM & \multicolumn{3}{|c|}{ NS } & \multicolumn{3}{|c|}{$*$} & \multicolumn{2}{|c|}{ NS } & \\
\hline $\mathrm{T} \times \mathrm{WCM}$ & \multicolumn{3}{|c|}{ NS } & \multicolumn{3}{|c|}{ NS } & \multicolumn{2}{|c|}{ NS } & \\
\hline
\end{tabular}

${ }^{\mathrm{e}} \mathrm{NT}=$ no tillage; $\mathrm{CT}=$ conventional tillage.

${ }^{y}$ Mean separation within columns by Tukey's honestly significant difference at $P \leq 0.05$.

ss, "Nonsignificant or significant at $P \leq 0.05$, respectively.

than if tilled before planting. Second, the allelochemical and smothering effects from the undisturbed, uniformly distributed cover crop residues most likely suppressed weed germination and seedling growth (Wallace and Bellinder, 1992). Although soil moisture was probably improved in the NT plots, which also would have favored weed growth, the combined stale-seedbed and allelopathic/ smothering effects apparently more than compensated for the increased weed growth potential, resulting in greater weed suppression in NT plots. This feature was particularly evident in FC sites, where between-row biomass was reduced in NT by $68 \%$ in $\mathrm{FC} / \mathrm{M}$ and $33 \%$ in $\mathrm{FC} / \mathrm{S}$; and in-row biomass was reduced in NT plots by $52 \%$ in $\mathrm{FC} / \mathrm{M}$ and $73 \%$ in $\mathrm{FC} / \mathrm{S}$.

Soil moisture content is usually higher in NT systems than in CT (Asoegwu, 1987; Coolman and Hoyt, 1993a; Doss et al., 1981). Even in irrigated crops, such as in our studies, the soil moisture content in NT plots normally is maintained at a more favorable (more available) level than in CT plots. Although overhead-sprinkler irrigation was applied (weekly, if no rainfall occurred) in our studies to supplement rainfall during the growing season, NT and CT plots were irrigated simultaneously and received the same amounts of water. Although caution was taken to avoid runoff of irrigation water from the experimental sites, probably a greater percentage of the seasonal rainfall infiltrated into NT plots than CT plots. Water infiltration is generally improved in NT systems compared to CT (Coolman and Hoyt, 1993a); thus, with heavy rains, commonplace in humid regions, water runoff is often less in NT systems (Coolman and Hoyt, 1993a).

Following each irrigation or rain during our experiments, evaporation would have been less in the mulched NT plots, resulting in maintenance of the soil moisture content at a more available level (Morse, 1993; Tessore, 1982). The "limited irrigation" regime followed in our experiments is typical of that practiced by most growers worldwide who use furrow or overhead-sprinkler irrigation systems (Hiller and Howell, 1983). Only with trickle-irrigation systems can most growers in the eastern United States afford to irrigate frequently enough to maintain the soil moisture content at ideal or optimum levels. Otherwise, in most situations with furrow or over- head irrigation systems, growers irrigate less (often considerably less) than needed, resulting in a fluctuating pattern of soil-moisture content in which intermittent periods of growthlimiting soil-moisture deficits occur throughout the growing season (Smittle et al., 1994; Unger et al., 1988). Thus, because of increased water infiltration and reduced soil-moisture evaporation in NT systems, crop yields and water-use efficiency, even in irrigated fields, are often improved in NT systems (Coolman and Hoyt, 1993a; Unger et al., 1988).

Effects of overseeded LMs and weeds on broccoli yield. Growth of the overseeded LMs in all sites were neither detrimental nor beneficial to broccoli growth and yield (Table 2). In three sites (FC/M, SC/R1, and SC/R2), weeds in non-HB plots were relatively sparse and did not reduce yields compared to the HB plots. Apparently, in these sites, the rapid and complete canopy closure within the broccoli twin rows was sufficient to suppress weed growth in NT and CT plots (Harper, 1980; Regnier and Janke, 1991). In FC/S, however, weed biomass in non-HB plots was prolific (about three to five times that of the other sites) (Fig. 2 ), resulting in a $20 \%$ yield reduction, compared to HB plots. Compared to control plots, overseeded LMs in FC/S had no effect on weed biomass or broccoli yield. Based on these data, overseeded legumes can decrease weed biomass without reducing broccoli yield when weed pressure is low; however, under heavy weed growth, broccoli yield can be reduced, and overseeded LM will have no significant effect on reducing weed biomass and alleviating yield decline.

Biomass and growth habit (architecture) of the interfering species (weeds or LM) could have reduced broccoli growth and crop yield in FC/S (Harper, 1983). The rapid growth and eventual height of the in-row biomass, especially redroot pigweed (Amaranthus retroflexus $\mathrm{L}$.), appeared to be a major factor that reduced broccoli yield in FC/S. In an earlier experiment conducted at the Kentland Agricultural Research Farm, Serage (1993) showed that broccoli yield was only reduced in LM plots in which between-row (3.1 Mg.ha- $\left.{ }^{-1}\right)$ and in-row (1.1 Mg.ha ${ }^{-1}$ ) total biomass (LM plus weeds) were relatively high. LM plots with high between-row $\left(3.6 \mathrm{Mg} \cdot \mathrm{ha}^{-1}\right)$ and low

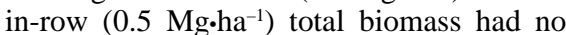

effect on broccoli yield (Serage, 1993). Data for FC/M (Fig. 2) showed results similar to those of Serage (1993) - the combination of high between-row (1.8 Mg.ha- $\left.{ }^{-1}\right)$ and low inrow $\left(0.4 \mathrm{Mg} \mathrm{ha}^{-1}\right)$ total biomass interference had no effect on broccoli yield. There was relatively little growth of redroot pigweed in FC/M, indicating that either there were fewer seeds of redroot pigweed present compared to $\mathrm{FC} / \mathrm{S}$ or that germination and seedling growth were inhibited by the heavy foxtail millet residues (Putnam and Weston, 1986). In FC/S, the combination of high between-row ( 5.8 $\mathrm{Mg} \cdot \mathrm{ha}^{-1}$ ) and high in-row (1.6 Mg.ha ${ }^{-1}$ ) total biomass reduced broccoli yield by $20 \%$ compared to HB plots.

High levels of between-row biomass may not reduce crop yield if water and nutrients are not limiting and the between-row biomass (either LM, weeds, or both) has a prostrate growth habit and, thus, does not tower above (shade) the main crop (Costello, 1994; Harper, 1983; Regnier and Janke, 1990; Serage, 1993). In our studies, the rapid canopy closure of the broccoli twin-row system was able to sufficiently suppress most weeds and LMs, except for the redroot pigweed in FC/S, to avoid yield-limiting competitive effects on broccoli yield. In FC/S, between-row and in-row growth of redroot pigweed was extensive in non-HB plots, the weeds reaching $120 \mathrm{~cm}$ high in many areas. Plants in all FC/S plots showed no visible symptoms of nutrient deficiency and Kjeldahl total $\mathrm{N}$ concentrations of broccoli leaves were the same for all treatments $(5.4 \%$ $\pm 0.3 \%)$. Plant stand and number of marketable heads did not vary among treatments; however, head size was smallest in non-HB plots (data not shown). Possibly, shading of broccoli plants by the redwood pigweed canopy reduced photosynthesis enough to decrease head size and yield. Nicholson and Wien (1983) suggested that light competition between white clover and cabbage may have been a factor in reducing cabbage yields because heavy clover growth shaded lower cabbage leaves. In the $\mathrm{SC}$ and FC/M sites, redroot pigweed did not become a yield-limiting factor, possibly because it was suppressed more by allelochemicals from rye (Shilling, 1983) in SC/R1 and SC/R2 and foxtail millet (Putnam and Weston, 1986) in FC/M than from soybean in $\mathrm{FC} / \mathrm{S}$. 
The data from our experiments show that the NT system resulted in as good or better broccoli transplant establishment as the CT system and that the effect was similarly encouraging for yield. Rapid canopy closure within the broccoli twin rows suppressed weeds and resulted in no yield reduction in control plots with NT and CT when weed pressures were relatively low. Weed suppression, however, was best in NT systems and, in combination with multiple-row plant arrangement and using dense allelopathic plant residues, NT systems appear to be promising for weed control as we move toward a more sustainable agriculture. Overseeding legume LMs suppressed weeds without reducing broccoli yields and, in fertile, irrigated fields, appears to be a useful method of establishing an overwintering cover crop for maintaining the continuity of residue cover in NT systems.

\section{Literature Cited}

Akobundu, I.O. 1980. Live mulch: A new approach to weed control and crop production in the tropics. Proc. 1980 British Crop Protection Conf.-Weeds 2:377-382.

Asoegwu, S.N. 1987. Comparison of tillage systems for the production of egusi-melon (Colocynthus citrullus $\mathrm{L}$.) and okra (Abelmoschus esculentus L.) in eastern Nigeria. Crop Res. (Hort. Res.) 27:77-90.

Bugg, R.L., S.C. Phatak, and J.D. Dutcher. 1990. Insects associated with cool-season cover crops. Implications for biological control in truckfarm and pecan ecosystems. Biol. Agr. Hort. $7: 17-45$.

Coolman, R.M. and G.D. Hoyt. 1993a. The effects of reduced tillage on the soil environment. HortTechnology 3:143-145.

Coolman, R.M. and G.D. Hoyt. 1993b. Increasing sustainability by intercropping. HortTechnology 3:309-312.

Costello, M.J. 1994. Broccoli growth, yield and level of aphid infestation in leguminous living mulches. Biol. Agr. Hort. 10:207-222.

Doss, B.D., J.L. Turner, and C.E. Evans. 1981. Influence of tillage, nitrogen, and rye cover crop on growth and yield of tomatoes. J. Amer. Soc. Hort. Sci. 87:123-126.

Foulds, C.M., K.A. Stewart, and R.A. Samson. 1991. On-farm evaluation of legume interseedings in broccoli, p. 179-180. In: W.L. Hargrove (ed.). Cover crops for clean water. Soil and Water Conservation Soc., Ankeny, Iowa.

Gomez, K.A. and A.A. Gomez. 1984. Statistical procedures for agricultural research. 2nd ed. Wiley, New York.

Graham, M.B. and G. Crabtree. 1987. Management of competition for water between cabbage (Brassica oleracea) and a perennial ryegrass (Lolium perenne) living mulch. Proc. Western Soc. Weed Sci. 40:113-117.

Harper, F. 1983. Competition-Inter-specific competition, p. 198-229. In: F. Harper (ed.). Prin- ciples of arable crop production. Granada Publ., London.

Hiller, E.A. and T.A. Howell. 1983. Irrigation options to avoid critical stress: An overview, $\mathrm{p}$. 479-497. In: H.M. Taylor, W.R. Jordan, and T.R. Sinclair (eds.). Limitations to efficient water use in crop production. Amer. Soc. Agron., Crop Sci. Soc. Amer., and Soil Sci. Soc. Amer., Madison, Wis.

Hoyt, G.D., D.W. Monks, and T.J. Monaco. 1994. Conservation tillage for vegetable production. HortTechnology 4:129-135.

Karlen, D.L. and D.E. Stott. 1994. A framework for evaluating physical and chemical indicators of soil quality, p. 53-72. In: J.W. Doran, D.C. Coleman, D.F. Bezdicek, and B.A. Stewart (eds.). Defining soil quality for a sustainable environment. Soil Sci. Soc. Amer. Spec. Publ. 35. Soil Sci. Soc. Amer. and Amer. Soc. Agron., Madison, Wis.

Knavel, D.E., and J.W. Herron. 1981. Influence of tillage system, plant spacing, and nitrogen on head weight, yield, and nutrient concentration of spring cabbage. J. Amer. Soc. Hort. Sci. 106:540-545.

Lal, R., E. Regnier, D.J. Eckert, W.M. Edwards, and R. Hammond. 1991. Expectations of cover crops for sustainable agriculture, p. 1-11. In: W.L. Hargrove (ed.). Cover crops for clean water. Soil and Water Conservation Soc., Ankeny, Iowa.

Lentner, M. and T. Bishop. 1993. Experimental design and analysis. 2nd ed. Valley Book Co., Blacksburg, Va.

Morse, R.D. 1993. Components of sustainable production systems for vegetables - Conserving soil moisture. HortTechnology 3:211-214.

Morse, R.D. 1995a. In-row soil loosening improves plant survival and yield of no-till cabbage and broccoli, p. 181-188. In: K.J. Bradford and T.K. Hartz (eds.). Proc. 4th Natl. Symp. on Stand Establishment, Monterey, Calif. 23-26 Apr. 1995.

Morse, R.D. 1995b. No-till, no-herbicide systems for production of transplanted broccoli, p. 113116. In: W.L. Kingery and N. Buehring (eds.). Conservation farming-A focus on water quality. Proc. Southern Region Conservation Tillage for Sustainable Agriculture, Jackson, Miss., 26-28 June 1995

Morse, R.D., D.H. Vaughan, and L.W. Belcher. 1993. Evolution of conservation tillage systems for transplanted crops; Potential role of the subsurface tiller transplanter (SST-T), p. 145-151. In: P.K. Billich (ed.). Proc Southern Conservation Tillage Conference for Sustainable Agriculture, Monroe, La., 15-17 June 1993.

Nicholson, A.G. and H.C. Wien. 1983. Screening turfgrasses and clovers for use as living mulches in sweet corn and cabbage. J. Amer. Soc. Hort. Sci. 108:1071-1076.

Norman, G.R. and D.L. Streiner. 1994. Biostatistics: The bare essentials. Mosby Year Book, St. Louis.

Peterson, H.C. and G.A. Chesters. 1964. A reliable total nitrogen determination on plant tissue and accumulating nitrate nitrogen. Agron. J. 56:89-90.
Putnam, A.R. and L.A. Weston. 1986. Adverse impacts of allelopathy in agricultural systems, $p$. 43-45. In: A.R. Putnam and C.S. Tang (eds.). The science of allelopathy. Wiley, New York.

Regnier, E.E. and R.R. Janke. 1990. Evolving strategies for managing weeds, p. 174-202. In: C.A. Edwards, R. Lal, P. Madden, R.H. Miller, and G. House (eds.). Sustainable agriculture systems. Soil and Water Conservation Soc., Ankeny, Iowa.

Schlotzhauer, S.D. and R.C. Littell. 1987. SAS system for elementary statistical analysis. SAS Inst., Cary, N.C.

Serage, T.I. 1993. Effects of overseeded legume living mulches and tillage on weed suppression and broccoli yield. MS Thesis, Viginia Polytechnic Inst. and State Univ., Blacksburg.

Shilling, D.G. 1983. The suppression of certain weed species by rye (Secale cereale $\mathrm{L}$.) mulch. Isolation, characterization, and identification of water-soluble phytotoxins from rye. PhD Diss., North Carolina State Univ., Raleigh.

Smittle, D.A., W.L. Dickens, and J.R. Stansell. 1994. Irrigation regimes affect cabbage water use and yield. J. Amer. Soc. Hort. Sci. 119:2023.

Standifer, L.C. and C.E. Beste. 1985. Weed control methods for vegetable production with limited tillage, p. 93-100. In: A.F. Wiese (ed.). Weed control in limited tillage systems. Weed Sci. Soc. Amer., Champaign, Ill.

Stoller, E.W. and R.A. Myers. 1989. Effects of shading and soybean (Glycine max L.) interference on Solanum ptycanthym (Dun.) (eastern black nightshade) growth and development. Weed Res. 29:307-316.

Tessore, C.M. 1982. Effect of tillage system and nitrogen rate on tomato yield. PhD Diss., Virginia Polytech. Inst. and State Univ., Blacksburg.

Tollenaar, M., A.A. Dibo, A. Aguilera, S.F. Weise, and C.J. Swanton. 1994. Effect of crop density on weed interference in maize. Agron. J. 86:591595.

Unger, P.W., E.W. Langdale, and P.J. Papendick. 1988. Role of crop residues-Improving water conservation and use, p. 69-100. In: W.L. Hargrove (ed.). Cropping strategies for efficient use of water and nitrogen. Amer. Soc. Agon. Spec. Publ. 51. Amer. Soc. Agron., Crop Sci. Soc. Amer., and Soil Sci. Soc. Amer., Madison, Wis.

Virginia Cooperative Extension. 1993. Virginia commercial vegetable production recommendations. Virginia Coop. Ext. Publ. 420-560, Blacksburg.

Wallace, R.W. and R.R. Bellinder. 1992. Alternative tillage and herbicide options for successful weed control in vegetables. HortScience 27:745749.

Wiles, L.J., R.D. William, G.D. Crabtree, and S.R. Radesevich. 1989. Analyzing competition between a living mulch and a vegetable crop in an interplanting system. J. Amer. Soc. Hort. Sci. 114:1029-1034.

Wilhoit, J.H., R.D. Morse, and D.H. Vaughn. 1990. Strip-tillage production of summer cabbage using high residue levels. Applied Agr. Res. 5(4):338-342. 